粘土の透水係数測定へのトランジェントパルス法の適用†

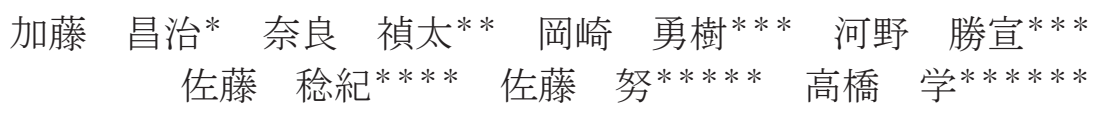

\title{
Application of Transient Pulse Method to Permeability Measurement for Clay
}

by

\author{
Masaji Kato*, Yoshitaka NarA**, Yuki OKaZAKI***, Masanori Kohno***, \\ Toshinori $\mathrm{SATO}_{* * * *}$, Tsutomu $\mathrm{SATO}^{* * * * * * \text { and Manabu TAKAHASHI } * * * * * *}$
}

To ensure the safe geological disposal of radioactive wastes, it is important to determine the permeability of clays. The transient pulse test is suitable to apply to the low permeability materials, because it takes relatively short term to determine the permeability. Usually we increase the upstream pore pressure in the measurement with the transient pulse test. However, it is impossible to determine the permeability of clay in this procedure because of the increase of pore pressure. Therefore, the transient pulse test has never been applied to the determination of permeability of clays. In this study, we tried to apply the transient pulse test to a clay obtained in Mizunami Underground Research Laboratory to determine the permeability with decreasing the downstream pore pressure. It was clarified that the transient pulse test with decreasing downstream pore pressure is appropriate from the measurement of granite. It was shown that the permeability of a clay was determined by the transient pulse test with decreasing the downstream pore pressure, which agreed with the permeability determined from the falling head test. The measurement time of the transient pulse test is much shorter than that of the falling head test. It is concluded that the transient pulse test is appropriate for the determination of the permeability of clays.

\section{Key words:}

Permeability test, Granite, Clay, Transient pulse method, Hydraulic conductivity

\section{1 緒言}

放射性廃棄物の地層処分においては，岩盤を天然バリ アとして使用する。このことから，低透水性の岩盤やき裂 を充填している粘土の存在は，より好ましい環境を提供 すると考えられる。したがって，天然バリアの性質を知る ためには，このような地質材料の透水係数の測定は欠か せない.

室内での透水係数の測定方法には, 定水位法 ${ }^{1)}$, 変水位 法 2)4), フローポンプ法 5),6), トランジェントパルス法 7)11)など, 複数の手法が提案されている。この中で, トラン ジェントパルス法は, 透水係数 $10^{-14} \sim 10^{-8} \mathrm{~m} / \mathrm{s}$ の材料の透 水係数測定に有効である ${ }^{12)}$. 通常, トランジェントパル ス法では，供試体をゴムスリーブやシリコンシーラント で被覆して圧力容器にセットし封圧を載荷し，封圧とは 独立に間隙水圧を制御できるようにして, 間隙水ライン の上流側の貯留槽圧を瞬時に上昇させる形で供試体の上
流側端面にパルス圧を与え, 間隙水が供試体内を拡散し ていく過程で上流側の貯留槽圧が低下しつつ下流側の貯 留槽圧が上昇していく様子を観測する.

低透水性の緻密な岩石では数多くのトランジェントパ ルス法の適用例 7) 11),13),14)がある. 一方で, 粘土も一般に低 透水性であるが，岩石の試験と同様の仕様と手順でパル ス法を適用寸ることは難しい. 通常, 粘土の透水試験や圧 密試験では, 試料を剛性の高い容器に収めて, 拘束圧を作 用させ, 排水・非排水を制御する. しかし, 岩石用の透水 試験装置では柔軟なジャケットで試料の被覆をするため, 剛性の低い粘土では，非排水条件で拘束圧を上げれば間 隙圧も上昇する. 排水条件においても, 拘束圧の載荷に粘 土試料の変形が即座に追随するのに対して, 粘土は低透 水性のため試料の排水が追いつかず，同様に間隙圧が上 昇するということになる. その後は徐々に変形が進み, 有 効応力が大きい場合には， ジャケットも大きく変形する

$\dagger$ 原稿受理 平成29年8月18日 Received Aug. 18, 2017 C2018 The Society of Materials Science, Japan

* 正 会 員 北海道大学 大学院工学研究院 $\overline{0} 060-8628$ 札幌市北区北13条西 Faculty of Eng., Hokkaido Univ., Kita-ku, Sapporo 060-8628

** 正 会 員 京都大学 大学院工学研究科 ₹615-8540 京都市西京区京都大学桂 Graduate School of Eng., Kyoto Univ., Nishikyo-ku, Kyoto 615-8540

*** 鳥取大学 大学院工学研究科 $\overline{0} 680-8552$ 鳥取市湖山町南

Graduate School of Eng., Tottori Univ., Koyama-Minami, Tottori 680-8552

***** 正会員 日本原子力研究開発機構 幌延深地層研究センター $\bar{T} 098-3224$ 北海道天塩郡幌延町 Horonobe Underground Res. Center, Japan Atomic Energy Agency (JAEA), Horonobe, Hokkaido 098-3224

****** 北海道大学 大学院工学研究院 $\overline{0} 060-8628$ 札幌市北区北13条西 Faculty of Eng., Hokkaido Univ., Kita-ku, Sapporo 060-8628

*******産業技術総合研究所 活断層・火山研究部門 テ305-8567 つくば市東 Res. Inst. of Earthquake and Volcano Geology, National Inst. of Adv. Industrial Sci. and Technol. (AIST), Higashi, Tsukuba 305-8567 
ことになり，間隙水が拘束圧媒体側に漏出する可能性が ある. そのため, 必然的に有効応力が 0 に近い状態で試験 を実施せざるを得ない.また，トランジェントパルス試験 において，上流側ライン圧を瞬時に上げると，元々拘束圧 と間隙圧が近い值のため，間隙圧が拘束圧を上回ること になり，間隙水が拘束圧媒体側に漏出し，実験が成立しな い。しかし，粘土の透水試験において，試験時間を短縮す るために，トランジェントパルス法の適用を考えること は，例えば試験中の温度管理の負担を軽減できるため有 意義である ${ }^{15)}$.また，これまで，粘土へトランジェントパ ルス法が適用された例はない。

そこで本研究では，粘土の透水係数測定にトランジェ ントパルス法の適用を考える. 特に, 岩石での適用性を検 証した上で, 同一の試験装置を用いて, トランジェントパ ルス法の粘土への適用の有効性を検討する.

\section{2 実 験 方 法}

\section{$2 \cdot 1$ 実験の概要}

本研究では, Fig. 1 に示す透水試験システムを使用した. 本システムは，加藤ら ${ }^{15}$ によって用いられたものと同一 の装置で，厳密な温度管理下でトランジェントパルス試 験が可能なのが特徴である.

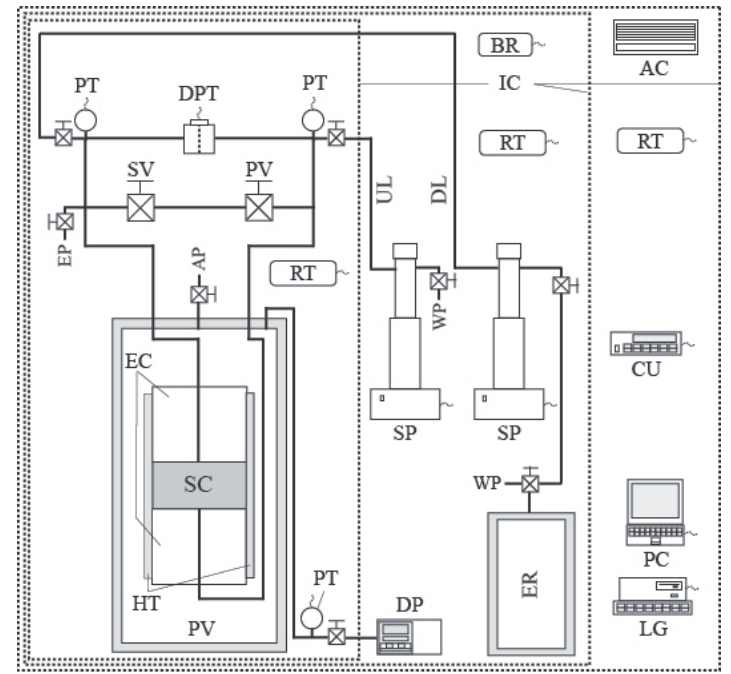

Fig. 1 Schematic illustration of permeability test system ${ }^{15)}$ (IC: Triple insulated chamber, AC: Air conditioner, RT: Resistance thermometer, BR: Barometer, PT: Pressure transducer, DPT: Differential pressure transducer, PV: Pressure vessel, ER: Extra reservoir, UL: Upstream line, DL: Downstream line, SV: Separation valve, PV: Pressure pulse valve, EP: Evacuating port, AP: Air discharge port, WP: Water supply port, SC: Specimen, EC: End caps, HT: Heat shrinkable tube, DP: Double plunger pump, SP: Syringe pump, CU: Controlling unit for syringe pumps, LG: Data logger, PC: Laptop)

トランジェントパルス法は, 高封圧・高間隙圧条件下に おける花崗岩の透水性評価のために, Brace et al.7)が提案 した試験方法であり，現在では短時間で低透水性岩石の 透水性を評価できる手法として確立されている. Brace et al.が材料の透水性評価のために導入した近似解は，式(1) の通りである。この解は多孔質媒体とみなせる材料す心゙ てに適用可能である。

$$
\frac{h_{u}-h_{d}}{H}=\exp \left\{-\frac{K A t}{l}\left(\frac{1}{S_{u}}+\frac{1}{S_{d}}\right)\right\}
$$

ここで, $H[\mathrm{~m}]$ はパルス水頭（初期水頭差）を示し， $h_{u}[\mathrm{~m}]$

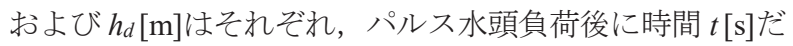
け経過したときの上流側および下流側の水頭で，この水 頭差の減衰曲線から透水係数 $K[\mathrm{~m} / \mathrm{s}]$ を評価できる. $l[\mathrm{~m}]$ と $A\left[\mathrm{~m}^{2}\right]$ はそれぞれ，供試体の長さと断面積である.

$2 \cdot 2$ 試料

本研究では, 岩石試料と粘土試料の二つを用意した. 岩 石試料は，中粒～粗粒の黒雲母花崗岩（土岐花崗岩）であ り，日本原子力研究開発機構東濃地科学センターより提 供を受けたボーリングコア（瑞浪超深地層研究所換気立 坑側 GL-200m 横坑において初期応力測定および室内物 理 - 力学試験用に削孔された 08MI14 号孔 : 深度 $7 \mathrm{~m}$ 付 近）の健全な部分を抽出し, 直径 $50 \mathrm{~mm}$, 高さ $25 \mathrm{~mm}$ の ディスク状に整形した。この花崗岩の間隙率は $0.8 \%$ であ る. 岩石試料の SEM 画像を Fig. 2 に示寸. 粘土試料は, 岩石試料が採取された坑道の壁面から採取し, 主に雲母 粘土鉱物からなる.この粘土の間隙比は約 2.6, 間隙率は 約 $72 \%$ である. 粘土試料の SEM 画像を Fig. 3 に, X 線回 折分析の結果を Fig. 4 に, 粒径分布を Fig. 5 にそれぞれ示 す．なお，本研究で用いた粘土は自立していない.

供試体は，デシケーター内で蒸留水に沈めた状態で数 時間真空脱気し，含水飽和させた，真空脱気後は，圧力 容器にセットするまでの間, 蒸留水に沈めたまま真空状 態で保管した。

粘土は, 岩石と違い自立していないため, 一般に透水試 験の際には剛性の高い容器に収め, 圧密度と飽和度を調 整して測定が実施される。しかし本研究では, 装置の違い の影響を避けるため，岩石供試体の測定に用いたものと 同じ透水試験装置を使用している. そのため, 粘土試料に 対しても，最終的に岩石供試体と同様の形状となるよう にゴムスリーブに試料を詰めて，供試体上下をエンドピ ースではさむようにしている.この試料を, Fig. 1 のよう に圧力容器内にセットし, 真空脱気後に蒸留水を供給す ることで含水飽和状態とし，シリンジポンプで間隙圧を 一定に保ち流量が 0 となることを確認している，すなわ ち, これにより試験結果へのサクションの影響が無視で きることになる．

一般に, 花崗岩と粘土の違いは次のようである. 花崗岩 は，高剛性であり，空隙率が低く，低透水性で低貯留性で ある。一方，粘土については，低透水性だけは花崗岩と同 じであるが，それ以外はすべて逆である. すなわち, 低剛 性, 高空隙率, 高貯留性ということになる. さらに, 花崗 岩の Skempton の $B$ 值が $0.55 \sim 0.85$ であるのに対して, 粘 土のそれは 0.99 という值が示されている ${ }^{16)}$. なお, 本研 究で使用した透水試験装置を構成している貯留槽や配管, 接手, バルブ等の剛性の相対的な低さから, 試料の $B$ 值 を直接正確に求めることはできない ${ }^{17)}$.

トランジェントパルス法では拘束圧をかけた状態でし か実験を実施できない。さらに粘土試料の試験では，粘 


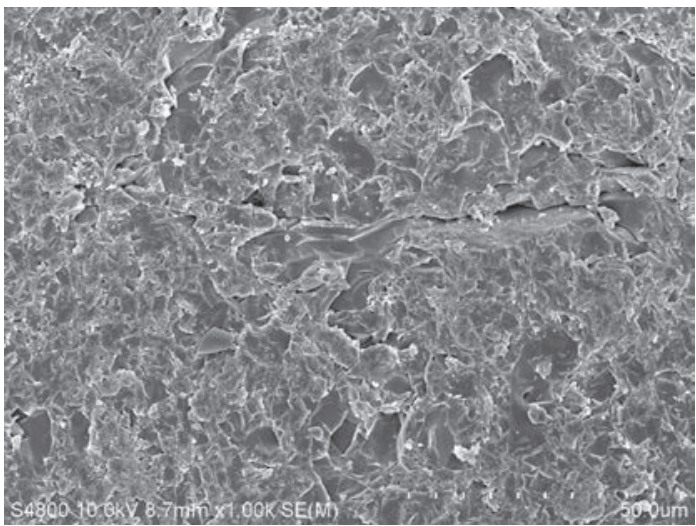

Fig. 2 SEM image of granite sample. Height and length of this image are $0.096 \mathrm{~mm}$ and $0.128 \mathrm{~mm}$, respectively.

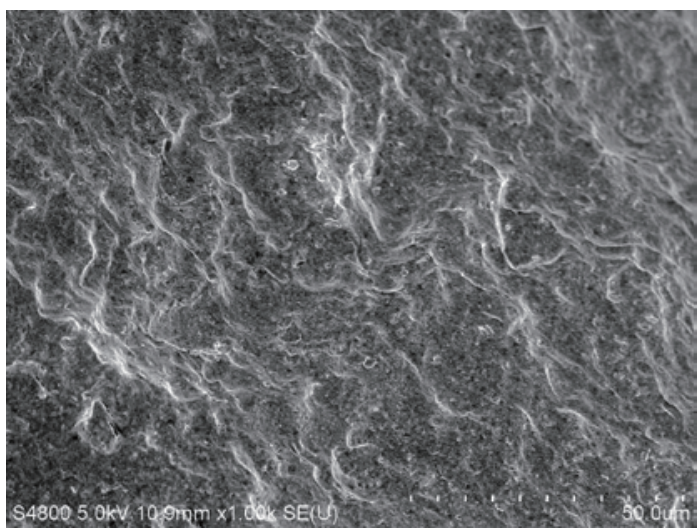

Fig. 3 SEM image of clay sample. Height and length of this image are $0.096 \mathrm{~mm}$ and $0.128 \mathrm{~mm}$, respectively.

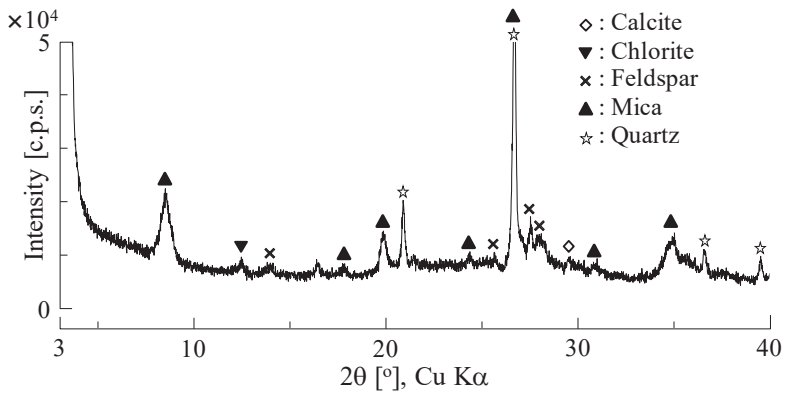

Fig. 4 XRD pattern of clay sample.

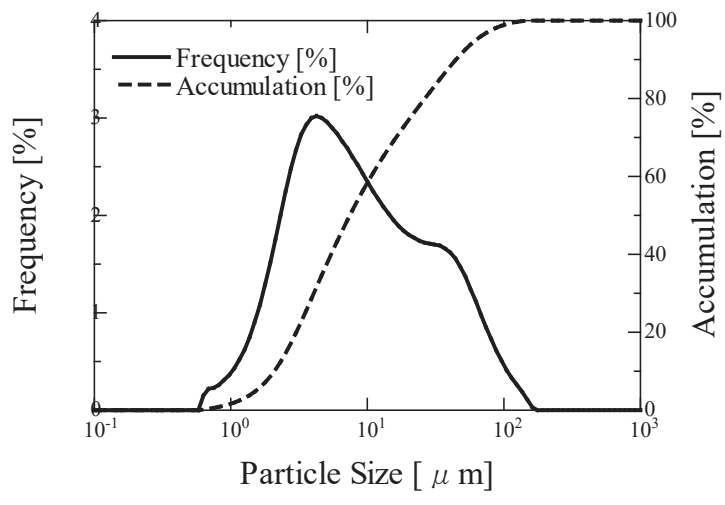

Fig. 5 Particle size distribution of clay sample.

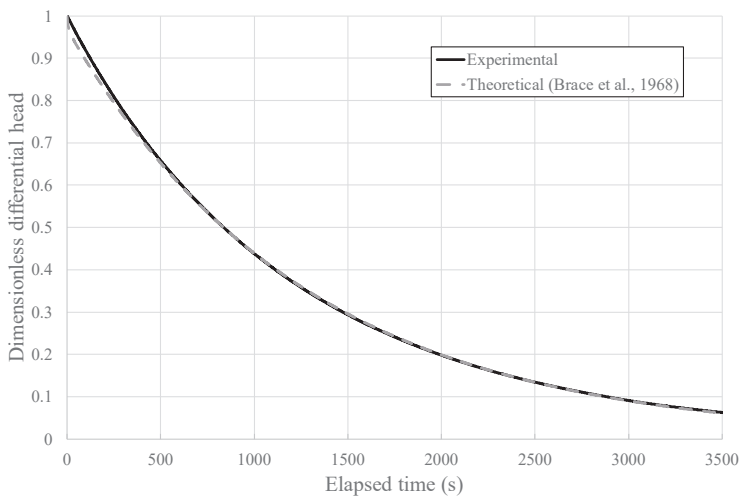

(a) Pressure pulse on upper side

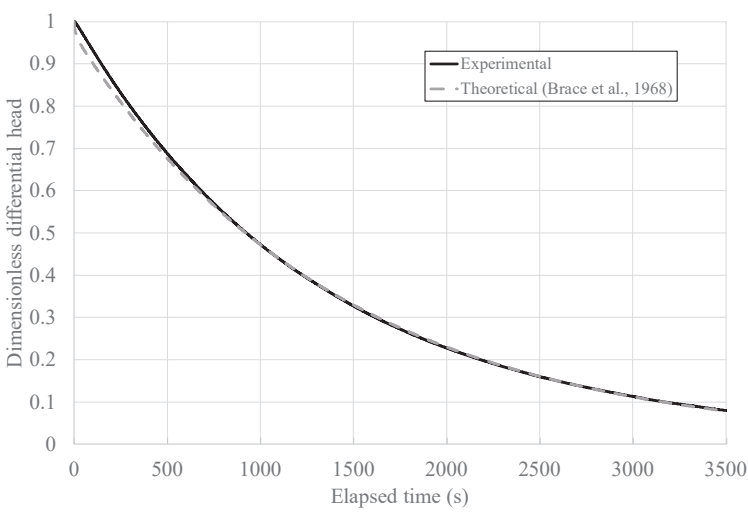

(b) Minus pressure pulse on lower side by decreasing pressure

Fig. 6 Decay of differential head during transient pulse permeability test for granite sample.

土の剛性が低いため，有効封圧を高く設定することがで きず（有効封圧を急に大きくすると，変形はそれに追随 するが，透水性が低いため閒隙圧が急激に上昇し，間隙 水が漏出することがあるため), 必然的に有効封圧が 0 に近い条件での実験となった。 なお，実験条件として封 圧は 0.6〜 4.1 MPa の範囲にあるので，深度 $200 \mathrm{~m}$ から採 取した試料に対しては, 過圧密領域で試験を実施したこ とになる。

\section{3 実 験 結 果}

Fig. 6 に土岐花崗岩におけるトランジェントパルス試験 で得られた差圧の経時変化を示寸. このときの有効封圧 は $1 \mathrm{MPa}$ である. Fig. 6a は上流側にパルス圧を加えたと き, Fig. $6 \mathrm{~b}$ は下流側に負のパルス圧を加えたとき（すなわ ち下流側の圧力を下げた場合）の差圧の経時変化である. 試験時間は，10\%までの減衰に 50 分程度，1\%まで減衰す るのに 110 分程度要した. このデータを用いて, Brace et al.の近似解から供試体の透水係数を求めた。 図中の破線 が, Brace et al.の近似解を用いて描いた近似曲線である. その結果，上流側に圧力パルスを加えたときの透水係数 は $4.32 \times 10^{-12} \mathrm{~m} / \mathrm{s}$ であり，下流側に負の圧力パルスを加え たときの透水係数は $3.77 \times 10^{-12} \mathrm{~m} / \mathrm{s}$ となった. 両者は良い 一致を示しており，花崗岩において上流側の圧力を上げ た場合でも下流側の圧力を下げた場合でも問題なくトラ 
ンジェントパルス法による透水試験が可能であることが 示された.

前述のように, 粘土試料においては, 上流側の圧力を上 げることは不都合である. そのため, 下流側の圧力を下げ る方法でトランジェントパルス透水試験を実施した。

Fig. 7 に下流側の圧力を下げた場合の粘土試料の差圧の 経時変化を示す．試験時間は，10\%まで減衰するのに 130 分以上要している. データを解析した結果, 粘土試料の透 水係数は $2.05 \times 10^{-11} \mathrm{~m} / \mathrm{s}$ となった. また, Fig. 8 に封圧が 異なるときの粘土の透水係数を誤差と共に示す.この図 において示されるように，透水係数の封圧依存性は見ら れない結果となった。これは, 有効封圧が変わらないため である。このように，粘土においても，トランジェントパ ルス法を用いて透水係数を短時間で求めることができた.

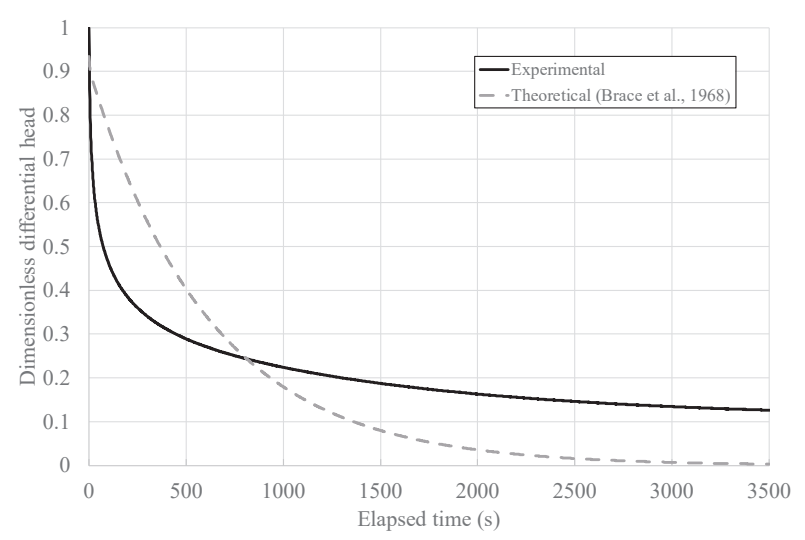

Fig. 7 Decay of differential head during transient pulse permeability test for clay sample.

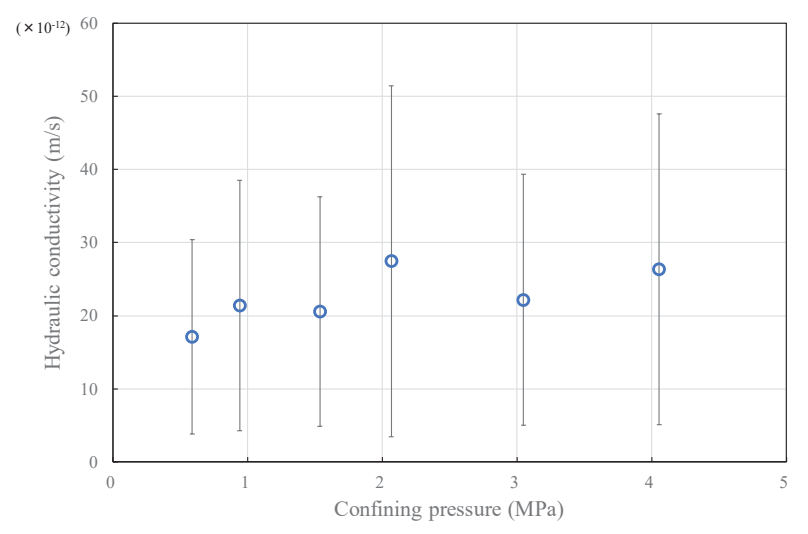

Fig. 8 Relationship between hydraulic conductivity and confining pressure for clay sample.

\section{4 考察}

花崗岩試料の透水試験結果から，上流側と下流側で圧 力を上げ下げしても問題ないことが示された.このこと から，上流側の間隙水圧を上昇させて試験を行うことが 困難な粘土試料でも，下流側の間隙水圧を下げるように してトランジェントパルス透水試験による測定が実施で きると判断できる.
ただし，トランジェントパルス透水試験により透水係 数を求めるためには，上流側と下流側の水頭差の減衰曲 線を得るということが必須である. 例えば, 透水係数が高 い材料の場合, 上流側と下流側に水頭差を与えても，一瞬 で水頭差がなくなってしまうため，減衰曲線を得ること は不可能である.このような場合は，トランジェントパル ス法による測定は不可能と断定できる.

一方, 本研究で用いた粘土試料では, 水頭差の減衰曲線 が得られたため, 透水係数の評価が可能であった. ただし， 花崗岩での結果と比べると, 粘土の場合は Brace et al.の近 似解（式(1)）とのズレが目立つ。これは, 花崗岩と粘土の 性質の違いによるものと思われる. 寸なわち, 2 ・2 節で 述べたように, 粘土が低剛性, 高空隙率, 高貯留性の材料 であることに起因すると思われる. Brace et al.の近似解は, 供試体の圧縮貯留量が装置の貯留槽の圧縮貯留量に比べ て無視できるほど小さいことを仮定している．このこと が実験值と理論值のズレとなって表れている.ただし, 実 験データと理論曲線が交わる点の両側のデータを利用す ることができれば, 近似解で評価される透水係数は，ある 程度の誤差は伴うが妥当な值となる。この誤差はデータ 解析で得ることができ，Fig. 8 にエラーバーとして表示さ れている. また, 過去に粘土のような土質材料でトランジ エントパルス法による測定は行われた例はない。そのた め, 透水係数の評価の妥当性に関しては, 従来良く用いら れた方法により得られた值と比較することによって検証 することが必要であろう。通常低透水性の土質材料では, 変水位法が用いられることが多い2 24$)$. そこで, 本研究で も変水位法を用いて, 粘土の透水係数測定を実施した.

変水位法では，下記の式を用いることによって透水係 数が評価される4).

$$
K=\frac{a l}{A t} \ln \frac{H_{u}-h_{d}}{h_{u}-h_{d}}
$$

ここで, $a$ はスタンドパイプの内空断面積 $\left[\mathrm{m}^{2}\right], H_{u}[\mathrm{~m}]$ は 試験開始時の上流側水頭 (初期水頭),$h_{u}[\mathrm{~m}]$ は任意の時間 $t$ での上流側の水頭, $h_{d}[\mathrm{~m}]$ は下流側の水頭である.

Fig. 9 に変水位法の装置を示す.この装置において, 写 真中の矢印の部分に試料が設置されている. また, この装 置のスタンドパイプは円形断面で, 直径は $54 \mathrm{~mm}$ である. また, 試料の長さ $l$ は $8 \mathrm{~mm}$ である. Fig. 10 に水頭差の経 時変化を示す. 変水位試験法による測定を行った結果, 粘 土の透水係数は $5.18 \times 10^{-10} \mathrm{~m} / \mathrm{s}$ となり, トランジェントパ ルス法での結果より 1 オーダー程度高くなった. この理 由として, Fig.9 の装置下部にあるように，試験に使用し た蒸留水中に粘土粒子が流出したためであると考えられ る. それでも, 透水係数の評価值は 1 オーダー程度の差に 収まっているので, 実験值としては妥当であろう。また, 変水位法での測定に要した時間（1 ケ月程度）は，トラン ジェントパルス法での測定時間（1 時間程度）よりもはる かに長くなっているため, 短時間で行えるトランジェン トパルス法での測定の方が，精度の高い実験を行う上で 明らかに好都合であるといえる。 


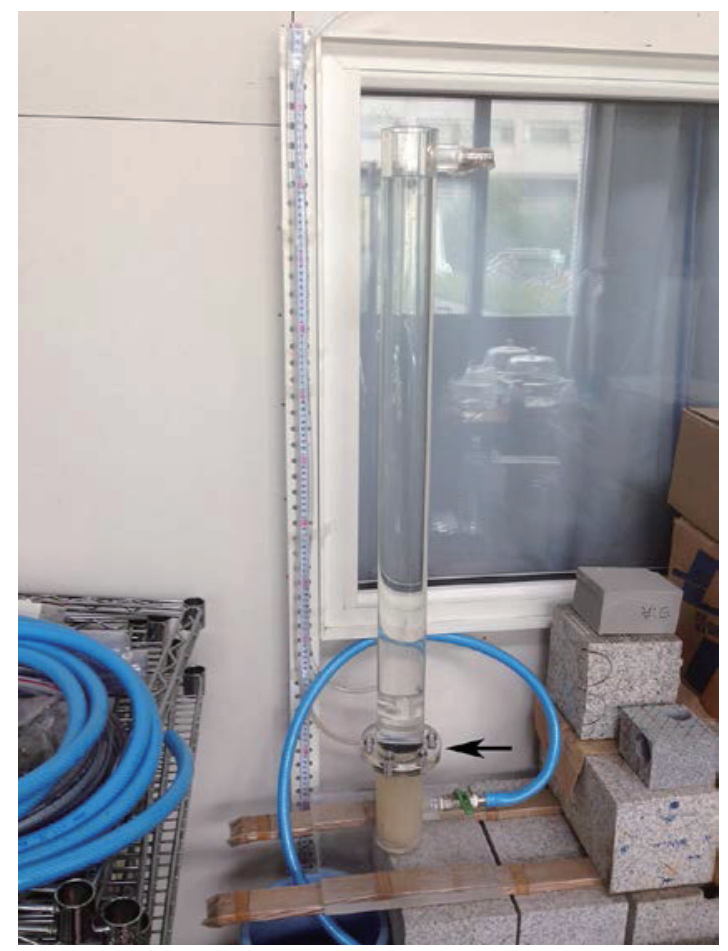

Fig. 9 Photo of apparatus for falling head test.

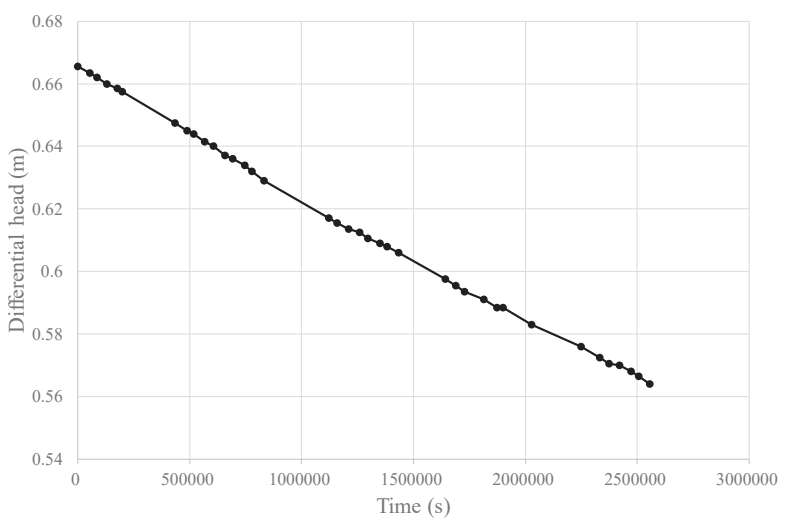

Fig. 10 Temporal change of differential head for falling head test with clay sample.

ただし，透水係数は，実験時の供試体の境界条件（特に 応力状態）に依存する. 変位境界条件に関しては, 定常流 れの透水試験においては影響ないが，非定常流れの透水 試験においては, 空隙の変形が伴うため水理定数（特に比 貯留率）の評価に影響を及ぼす。このことから, 装置の違 いが試験時の境界条件の違いにつながるのであれば，透 水試験結果に影響を及ぼすということになる，異なる透 水試験で得られる透水係数は，それぞれの透水試験の境 界条件における透水係数と解釈する必要がある。そのた め, 試験時の境界条件が，目的としている条件となってい るのかは確認することが必要である。粘土試料へのトラ ンジェントパルス法の適用に際しては，岩石試料のとき と同じ装置で試験を実施している，粘土試料のトランジ エントパルス透水試験においては，2・2 節で述べたよう に, 必然的に有効応力がほぼ 0 の状態で試験が行われた.
一方で，このトランジェントパルス法の結果の妥当性を 判断するために実施した簡易な変水位試験においても, 必然的に有効応力がほぼ 0 という条件となっている. 変 位境界条件については, トランジェントパルス法ではゴ ムスリーブを使用しているため変形する可能性がある。

一方で変水位法では剛的な容器に試料を詰めるため側方 への変形はなく, こちらのほうがき裂を充填している粘 土の状態としては好ましい条件である可能性はある。

放射性廃棄物地層処分では粘土（特にベントナイト）を 緩衝材として用いるため, 粘土における透水係数の測定 は極めて重要である.また, 岩石内にはしばしば巨視的な き裂が含まれているが, そのき裂内は, 粘土のような微細 な鉱物粒子で充填されていることが多い. Mitchell and Faulkner ${ }^{18)}$ は，粘土のような微細な物質がき裂を充填する ことによって, 岩石の透水性が低下寸る可能性を指摘し ている.このことは, Nara et al. ${ }^{19), 20)}$, Wang et al. ${ }^{21)}$, PerezFlores et al. ${ }^{22)}$ の一連の研究により明らかになり，火成岩の ような緻密な岩石では, 巨視き裂が含まれている場合，き 裂内部が粘土のような微細な物質で充填されているか否 かで透水性が大きく異なり, 微細な物質の透水性が岩石 全体の透水性に大きく影響することが明らかになってい る.また，断層運動により損傷を受けた断層周辺の岩盤 では，発達したき裂によって短期的には選択的に地下水 や物質の移動経路となるが，長期的には微細鉱物による き裂閉塞が起こり，地下水や物質の移動が抑制される可 能性が指摘されている ${ }^{23)}$. つまり, 粘土のように, き裂 を充填する可能性がある物質の透水性を評価すること は, 岩盤の遮蔽性能を知る上で重要であり, 本研究で示 された短時間で測定可能なトランジェントパルス法の 適用は極めて有意義であると考えられる。

\section{5 結 言}

本研究では，岩石試料および粘土においてトランジェ ントパルス法を用いて透水係数を測定した。 とくに, 岩石 で上流側を上げる場合と下流側を下げる場合で比較して, 問題ないことを確認した. 粘土では, 下流側を下げる場合 で透水係数を求め, 変水位法で得られた值と比較して, 問 題ないことを確認した.

トランジェントパルス法は短時間で透水係数を測定で きる非常に便利な測定方法である。粘土のような低透水 性の土質材料でも下流側を下げることによって実行可能 であるため，その有用性が極めて高いと結論づけられる.

本研究は，「放射性廃棄物共通技術調査等事業（放射性 廃棄物重要基礎技術研究調査)」（2014～2017 年度）のサ ポートを受けて実施した。

\section{参 考 文 献}

1) H. Darcy, Les Fontaines Publiques de la Ville de Dijon, (Victor Dalmont, Paris, 1856), 647p.

2) K. Terzaghi, Erdbaumechanik auf bodenphysikalischer Grundlage, (Franz Deuticke, Leipzig und Wien, 1925), 399p. 
3) K. Terzaghi, "Sickerverluste aus kanalen", Die Wasserwirtschaft, Vol.23, No.18/19, pp.318-330 (1930).

4) G. Gilboy, "Soil mechanics research", Proceedings of the American Society of Civil Engineers, Vol.57, No.8, pp.1165-1188 (1931).

5) H. W. Olsen, "Darcy's law in saturated kaolinite", Water Resources Research, Vol.2, No.2, pp.287-295 (1966).

6) R. H. Morin and H. W. Olsen, "Theoretical analysis of the transient pressure response from a constant flow rate hydraulic conductivity test", Water Resources Research, Vol.23, No.8, pp.1461-1470 (1987).

7) W. F. Brace, J. B. Walsh and W. T. Frangos, "Permeability of granite under high pressure", Journal of Geophysical Research, Vol.73, No.6, pp.2225-2236 (1968).

8) P. A. Hsieh, J. V. Tracy, C. E. Neuzil, J. D. Bredehoeft and S. E. Sillman, "A transient laboratory method for determining the hydraulic properties of 'tight' rocks - I. theory", International Journal of Rock Mechanics and Mining Sciences \& Geomechanics Abstracts, Vol.18, No.3, pp.245-252 (1981).

9) M. Zhang, M. Takahashi, R. H. Morin and T. Esaki, "Evaluation and application of the transient-pulse technique for determining the hydraulic properties of low-permeability rocks - part 1: theoretical evaluation", Geotechnical Testing Journal, Vol.23, No.1, pp.83-90 (2000).

10) M. Kato, M. Takahashi and K. Kaneko, "Theory of permeability test methods for measuring hydraulic constants of porous media in laboratory", Journal of MMIJ, Vol.129, No.7, pp.409-417 (2013).

11) M. Kato, M. Takahashi and K. Kaneko, "Highly precise evaluation of hydraulic constants of low-permeability rocks using the transient pulse method", Journal of MMIJ, Vol.129, No.7, pp.472-478 (2013).

12) Japanese Geotechnical Society : Sekkeiyou Jiban Teisu no Kimekata - Ganban-hen - (2007)

13) M. Takahashi and Z. Xue, "On problem in measuring permeability of rocks using pulse method", Chishitsu News, No.421, pp.46-54 (1989).

14) M. Zhang, M. Takahashi, R. H. Morin and T. Esaki, "Evaluation and application of the transient-pulse technique for determining the hydraulic properties of low-permeability rocks - part 2: experimental application", Geotechnical Testing Journal, Vol.23, No.1, pp.91-99 (2000).

15) M. Kato, Y. Nara, D. Fukuda, M. Kohno, T. Sato, T. Sato and M. Takahashi, "Importance of temperature control in surrounding environment during permeability test for measuring hydraulic constants of rock", Journal of the Society of Materials Science, Japan, Vol.65, No.7, pp.489-495 (2016).

16) H. F. Wang, Theory of Linear Poroelasticity with Applications to Geomechanics and Hydrogeology, (Princeton University Press, Princeton, 2000), 266p.

17) T. Tokunaga, R. Aoyagi, K. Mogi, H. Kameya and H. Tosaka, "Determination of hydraulic conductivity and storage coefficient through simultaneous measurements of fluid pressure and strains", Journal of the Japan Society of Engineering Geology, Vol.42, No.4, pp.208-213 (2001).

18) T. M. Mitchell and D. R. Faulkner, "Experimental measurements of permeability evolution during triaxial compression of initially intact crystalline rocks and implications for fluid flow in fault zones", Journal of Geophysical Research, Vol.113, B11412, doi: 10.1029/2008JB005588 (2008).

19) Y. Nara, P.G. Meredith, T. Yoneda and K. Kaneko, "Influence of macro-fractures and micro-fractures on permeability and elastic wave velocities in basalt at elevated pressure", Tectonophysics, Vol.503, No.1-2, pp.52-59 (2011).

20) Y. Nara, M. Kato, R. Niri, M. Kohno, T. Sato, D. Fukuda, T. Sato and M. Takahashi, "Permeability of granite including macro-fracture naturally filled with finegrained minerals", Pure and Applied Geophysics, in press (2017). doi: 10.1007/s00024-017-1704-x

21) G. Wang, T.M. Mitchell, P.G. Meredith, Y. Nara and Z. $\mathrm{Wu}$, "Influence of gouge thickness on permeability of macro-fractured basalt", Journal of Geophysical Research - Solid Earth, Vol.121, pp.8472-8487 (2016).

22) P. Perez-Flores, G. Wang, T.M. Mitchell, P.G. Meredith, Y. Nara, V. Sakar and J. Cembrano: "The effect of offset on fracture permeability of rocks from the Andean Southern Volcanic Zone, Chile", Journal of Structural Geology, Vol.104, pp.142-158 (2017).

23) M. Ishibashi, H. Yoshida, E. Sasao and T. Yuguchi, "Long term behavior of hydrogeological structures associated with faulting: An example from the deep crystalline rock in the Mizunami URL, Central Japan", Engineering Geology, Vol.208, pp.114-127 (2016). 